\title{
一定引張軸力を受ける露出柱脚の抵抗機構と復元力特性モデル MODELS OF RESTORING FORCE CHARACTERISTICS \& RESISTANT MECHANISMS OF EXPOSED COLUMN-BASE UNDER CONSTANT TENSILE AXIAL-FORCE
}

\author{
山西央朗*, 高松隆夫**, 玉井宏章***, 松村高良****, 松 尾 彰***** \\ Teruaki YAMANISHI, Takao TAKAMATSU, Hiroyuki TAMAI, \\ Takayoshi MATSUMURA and Akira MATSUO
}

\begin{abstract}
An anchor-bolt-yield-type column base shows slip-type restoring force characteristics. The column base subjected to constant axial and cyclic horizontal forces shows more complicated characteristics. An experimental study on the column-bases under constant axial-force and cyclic bending was carried out. The following conclusions were obtained from the loading tests;

1) Three types of resistant mechanisms of the column-base under constant axial-force were classified to evaluate the strength and the elastic rotational stiffness.

2) In case of tensile axial-force $N=57(\mathrm{kN})$, the restoring force characteristics of the column-base were obtained combined all types of the resistant mechanisms.

3) In case of tensile axial-force $N=117(\mathrm{kN})$, the restoring force characteristics became perfectly elasto-plastic curves without slip behavior.
\end{abstract}

Keywords : Exposed column-base, Anchor-bolt-yield-type, Restoring force characteristics,

Constant tensile axial-force, Cyclic loading tests

露出柱脚, アンカーボルト降伏先行型, 復元力特性, 引張軸力, 繰返し載荷実験

\section{1. はじめに}

アンカーボルト降伏先行型露出柱脚の降伏曲げ耐力，弾性回転剛 性は, 柱軸力の影響を受けて増減する ${ }^{1-2)}$. 柱脚には上部構造物の自 重等による圧縮軸力が常時作用しており, 中柱の柱脚においては, 地震時でも一定圧縮軸力が作用すると仮定できる場合が多い，この ような, 一定圧縮力を受ける場合の露出柱脚に関する研究としては, アンカーボルト降伏先行型露出柱脚で発生するスリップ現象に着目 した研究が, 数多く行われている. また, 著者等は, このスリップ 現象を改善する装置として”楔デバイス”を提案・研究しており ${ }^{3-12)}$, 中柱を想定した一定圧縮軸力下において, スリップ現象を改善した 復元力特性を付与できることを示している. ”楔デバイス”はナッ トとベースプレートの間に隙間が生じればその間隙を楔が埋めてス リップ現象の改善が期待でき, 文献 13)において, 圧縮軸力領域の変 動軸力を受ける場合でも期待する性能が得られることを示している. しかしながら, 変動軸力が引張領域に達する場合については検討を 行っていない.

一方, 側柱においては変動軸力が作用し, 軸力が弓張軸力となる可 能性もある. 引張軸力領域を含む変動軸力に関する研究は, いくつか 報告されている ${ }^{14-20)}$. 伊藤・三谷・田中等は ${ }^{14-16)}$, 変動軸力を受ける
場合の露出柱脚における要素実験・露出柱脚付き単層多スパンラーメ ン架構の実験により，変動軸力を受ける露出柱脚が上部構造物に与え る影響を明らかにし，ラーメン架構側柱において変動軸力が発生する こと, 軸力の変動が小さい場合, 変動軸力による保有水平耐力や水平 剛性に与える影響が小さいことを示している，また，田沼・橋本 ${ }^{17)}$ や宗宮・福知等 ${ }^{18)}$ は, 要素実験を行うと共に, 引張軸力領域を含む 変動軸力下における抵抗機構および各評価式を検討・提案している. そして, 著者の一人は ${ }^{19-20)}$, 変動軸力を受ける場合の各種抵抗機構, 軸力 - 曲げ相関降伏耐力式を示すと共に, 引張軸力領域におけるせん 断スリップ条件を明らかにしている.

これらの研究は, 特定の変動軸力下における限定的な復元力特性 モデルの定式化である点, 抵抗機構と復元力特性モデルとの対応が 明解でない点, また, 実験的に検証が不十分である点等で抵抗機構 に基づく復元力特性モデルを明らかにしているとは言えない. 著者 等は，今後，“楔デバイス”を用いた側柱柱脚を取扱うにあたり，” 楔デバイス”が期待通りの性能を発揮することを実証・検証する上 で, 引張軸力領域を含んだ変動軸力を受ける場合の抵抗機構に基づ く復元力特性モデルを精確に評価しなければならない. しかしなが ら, 引張軸力を受ける場合の抵抗機構および復元力特性モデルの提

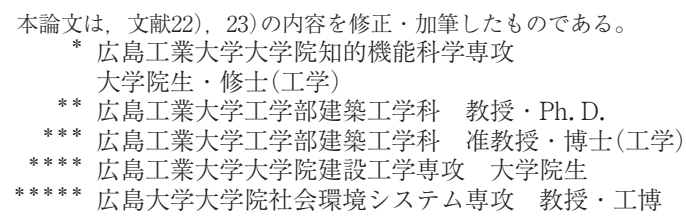

Graduate Student, Graduate School of Eng., Hiroshima Institute of Technology, M. Eng.

Prof., Faculty of Eng., Hiroshima Institute of Technology, Ph. D.

Assoc. Prof., Faculty of Eng., Hiroshima Institute of Technology, Dr. Eng. Graduate Student, Graduate School of Eng., Hiroshima Institute of Technology Prof., Graduate School of Eng., Hiroshima University, Dr. Eng. 
表 1 素材特性と主要寸法

\begin{tabular}{|c|c|c|c|c|}
\hline & 材質 & $\begin{array}{l}E \\
\left(\mathrm{~N} / \mathrm{mm}^{2}\right)\end{array}$ & $\begin{array}{l}\sigma_{Y} \\
\left(\mathrm{~N} / \mathrm{mm}^{2}\right)\end{array}$ & $\begin{array}{l}\text { 主要寸法 } \\
(\mathrm{mm})\end{array}$ \\
\hline 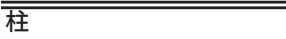 & STKR400 & 205,000 & 414 & Box-200x200x12 \\
\hline ベースプレート & SS400 & 205,000 & 274 & PL-400x400x50 \\
\hline アンカーボルト: C60, T30 & ABR400 & 205,000 & 315 & $\phi_{g}=14.5,{ }_{a b} \ell=590$ \\
\hline$: \mathrm{T} 60$ & ABR400 & 205,000 & 294 & $\phi_{g}=14.6,{ }_{a b} \ell=445$ \\
\hline
\end{tabular}

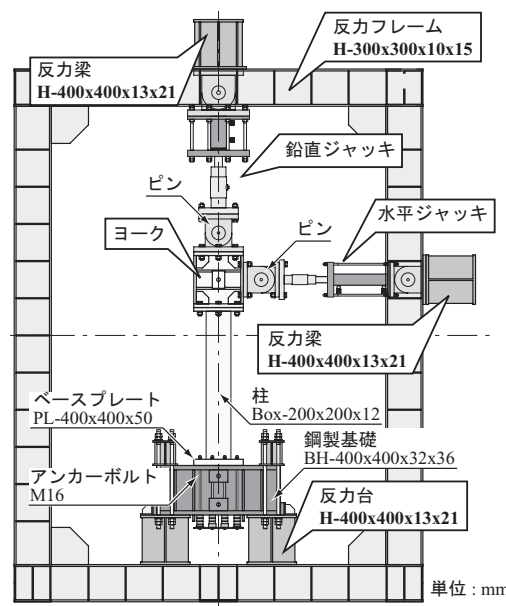

図 2 載荷装置

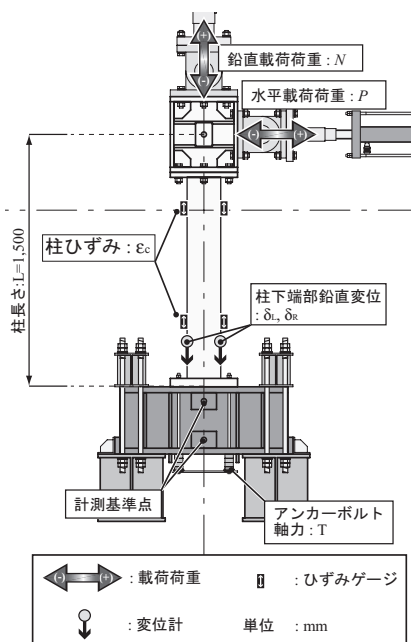

図 4 計測位置
案もほとんどなされていないため, 引張軸力領域を含む変動軸力を 受ける場合の抵抗機構に基づく復元力特性モデルを直接的に検討す ることは困難であると思われる. そこで, 引張軸力下の基本的な挙 動を明確にするために，先ず，一定引張軸力を受ける場合の露出柱 脚の復元力特性を検討する. 一定圧縮・引張軸力を受ける露出柱脚 については, 九谷・増田 ${ }^{21)}$ が載荷実験を行っているものの, 終局而 力の評価に着目しての研究が行われており, 抵抗機構および復元力特 性モデルについては検討されていない.

このような背景の下，本論文では，一定圧縮・引張軸力を受ける アンカーボルト降伏先行型露出柱脚の抵抗機構および復元力特性を 明らかにするために, 水平繰返し載荷実験を行う。そして, 一定軸力 を受ける柱脚における抵抗機構, 復元力特性, それらの間の対応関係 を明らかにして, 今後の, 変動軸力下の載荷実験, 特に, ”楔デバイ ス”を用いた場合の抵抗機構および復元力特性の検討を行うにあたつ ての基礎資料を得ることを目的とする.

\section{2. 実験}

本実験では, 露出柱脚付き片持ち柱に一定柱軸力を載荷した後に, 水平繰返し載荷実験を行う。試験体变数を, 柱軸力 $: N$ とする.

\section{1 試験体}

表 1 に試験体の素材特性と主要寸法を示す。また, 図 1 に試験体 形状を示す，尚，本実験では，ベースプレート，柱，および，基礎 部分には，各載荷に対して弾性範囲に留まる素材特性・断面性能を 採用している.

試験体には，柱軸力として一定圧縮軸力 $125(\mathrm{kN})(\mathrm{Comp})$ ，一定 引張軸力 $57(\mathrm{kN})($ Ten I), 一定引張軸力 $117(\mathrm{kN})$ (Ten II) を載荷する, 合計 3 種類を用意した. (柱軸力の決定方法は, 後述の 2.2 節に示す. )

柱には Box-200x200x12，ベースプレートには隅角部にアンカーボ ルトを 1 本ずつ計 4 本配置する PL-400x400x50 を用い，柱とベース

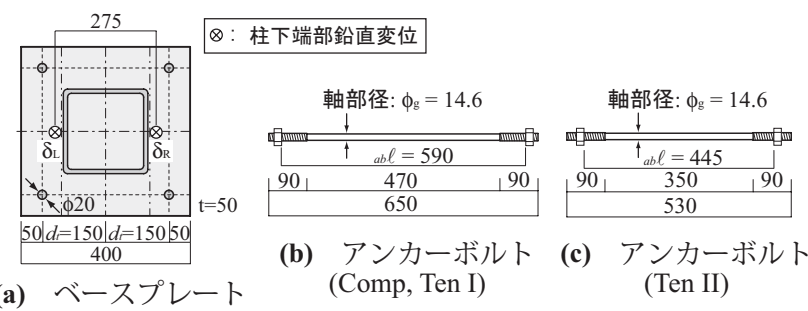

図 1 試験体形状

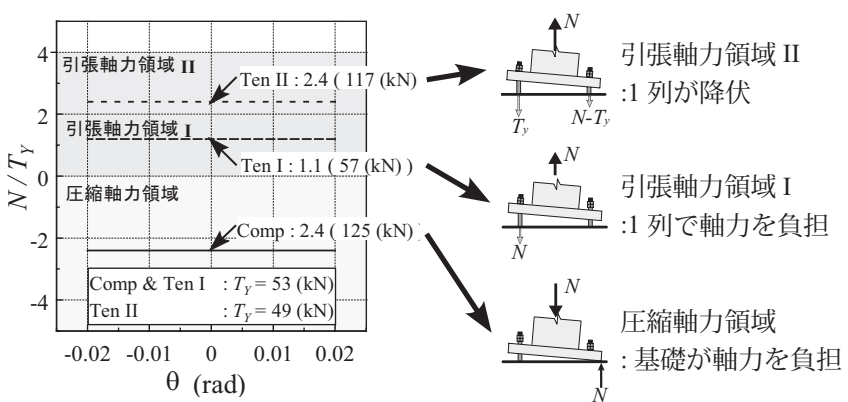

図 3 鉛直荷重

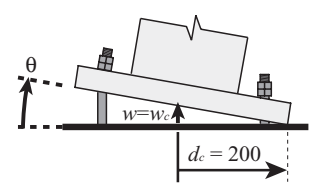

(a) 接触状態

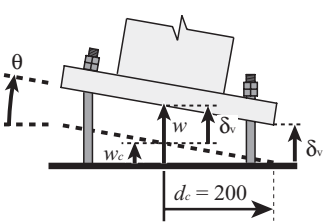

(b) 離間状態
図 5 接触・離間の状態と幾何学的条件

プレートとは全周隅肉溶接接合している．アンカーボルトには転造 ねじアンカーボルト M16 を使用し，軸部降伏軸力の $30 \%(15 \mathrm{kN})$ を 初期張力として導入する．基礎部には，いずれの載荷に対しても塑 性化しない，鋼製基礎 :BH-400x400x32x36 を使用する.

\section{2 載荷装置と載荷方法}

図 2, 3 に載荷装置，各試験体に載荷する鉛直荷重を示す．載荷 装置は, 試験体柱頭部のヨークヘ鉛直・水平ジャッキを取付け, 鉛直・ 水平載荷を行うものである.

水平載荷は, 制御值をべースプレート回転角 : $\theta$ として, 0.005(rad) から 0.02(rad) まで $0.005(\mathrm{rad})$ ずつ振幅を漸増させる正負交番漸増繰 返し載荷とする.

鉛直載荷としては, 図 3 に示す 3 種類の一定軸力を採用する. 尚, 本載荷装置では, ヨークの移動・回転による柱軸力の増減が生じる と考えられるが, 軸力の増減は土 $5 \%$ 以下であり, 本実験における影 響はないものとして取扱う。

各柱軸力において, まず，圧縮軸力の場合 (圧縮軸力領域) には, 常にベースプレートが基礎に接触しており，柱軸力はベースプレー トを介して基礎に伝播されるため，柱軸力が増減しても抵抗機構は 変化しない. このため, 柱軸力による付加曲げ抵抗が確認できる程 度の軸力の大きさとして $N=-125(\mathrm{kN})$ を採用している.

次いで, 引張軸力の場合には, 柱軸力をアンカーボルトが負担す るので，1）1列のアンカーボルト（本試験体は，2 本/列）のみで柱 軸力に抵抗できる場合；2１１列のアンカーボルトのみでは降伏するた めに, 全アンカーボルトで抵抗する場合; とがあり, 柱脚が降伏する 時 (アンカーボルト降伏時) の抵抗機構が変化する. すなわち, アン カーボルト降伏軸力 $: T_{Y}$, 引張側アンカーボルト本数 $: n$ を用いて, 以 下のように領域を分ける必要がある. 


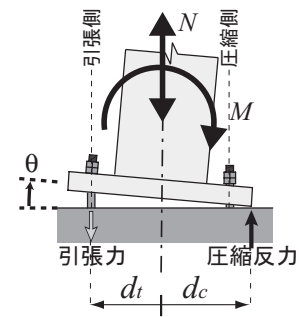

(a) 抵抗機構 $\mathrm{A}$

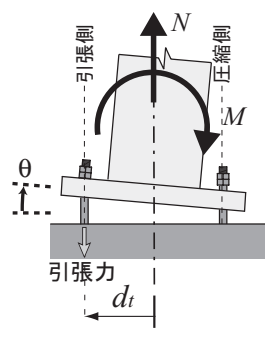

(b) 抵抗機構 B

図 6 抵抗機構

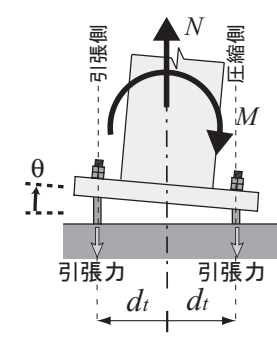

(c) 抵抗機構 $\mathrm{C}$
$0<N<4 \cdot T_{Y}$ を満足すると共に,

$N<n \cdot T_{Y}=2 \cdot T_{Y}:$ 引張軸力領域 $\mathrm{I}$

$N \geq n \cdot T_{Y}=2 \cdot T_{Y}:$ 引張軸力領域 II

本実験においては, 柱軸力がアンカーボルト 2 本分の降伏耐力を 超過するか否かが境となり, 柱脚の抵抗機構が変化する. それぞれ, 引張軸力領域 I では $N=57(\mathrm{kN})$, 引張軸力領域 II では $N=117(\mathrm{kN})$ を採 用している.

\section{3 計測方法と整理方法}

図 4, 図 5 に計測位置, ベースプレートと基礎との接触・離間時 の幾何学的条件を，それぞれ，示す．変位としては，柱下端部の鉛 直変位 $: \delta_{L}, \delta_{R}$ (図1(a) 参照) を計測してベースプレート回転角 : $\theta$, 柱 図心位置鉛直変位: $w$ を算出する. 荷重としては, 各ジャッキ先端 に設置したロードセルにより水平荷重: $P$ および鉛直荷重 $: N$ を, ア ンカーボルト下端部に設置したセンターホール型ロードセルにより アンカーボルト軸力 $: T$ を計測する. また, ひずみゲージを柱の 2 断 面 (1 断面当たり, 4 䇢所) に貼付して, 柱の軸方向直ひずみを計測し, 曲率と柱の曲げ剛性から柱脚部に作用する曲げモーメント : $M$ を算 出する. 尚, ひずみゲージょり算出した, 曲げモーメント勾配から 柱のせん断力を算出し, 水平荷重 $: P$ と一致することを確認している.

また, 引張軸力を受ける場合, ベースプレートが基礎から離間す る場合がある. この離間変位 : $\delta_{v}$ を, 以下のように算出する.

先ず，ベースプレートが基礎に接触している状態の柱図心位置鉛 直変位: $w_{c}$ を, 図 $5(\mathrm{a})$ に示す変形状態の幾何学的条件より, 以下の ように表すことができる.

$$
w_{c}=d_{c} \cdot \sin \theta
$$

次いで, 図 5(b) に示すように離間している状態における離間変位 : $\delta_{v}$ を, 柱眓心位置鉛直変位: $w$ と, $w_{c}$ を用いて, 以下の式で表すこ とができる.

$$
\delta_{v}=w-w_{c}=w-d_{c} \cdot \sin \theta
$$

ここに, $\theta:$ ベースプレート回転角, $d_{c}$ : 柱図心位置からベースプレー ト端部までの距離 (図 5 参照) である.

\section{3. 抵抗機構と復元力特性モデル}

一定圧縮・引張軸力を受ける露出柱脚について, 図 6 に示す 3 種 類の抵抗機構を用いて, 付加曲げ抵抗, 降伏曲げ耐力, 弾性回転剛 性の評価式の導出, 並びに, 復元力特性モデルの定式化を行う.

尚, 本論文では繰返し載荷時の挙動に主眼を置いて復元力特性モ デルの定式化を行う，単調載荷時には，如何なる柱軸力を受ける場 合にも, 全てのアンカーボルトのナットがベースプレートに接触し ており，本論文で示す内容と異なる部分がある.
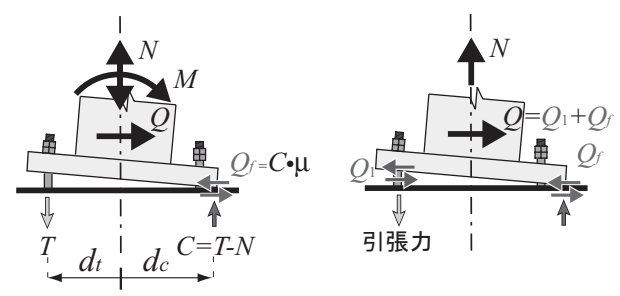

(a) せん断抵抗状態 $\mathrm{A}$

(b) せん断抵抗状態 B
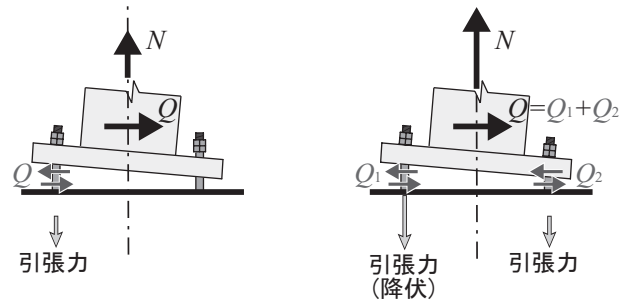

(c) せん断抵抗状態 $\mathrm{C}$

(d) せん断抵抗状態 D

図 7 せん断力に対する抵抗機構 ${ }_{a b} Q /\left(n \cdot Q_{Y}\right)$ $\left(Q_{Y}\right.$ :アンカーボルトの降伏せん断カ $\left.(=28.4(\mathrm{kN}))\right)$

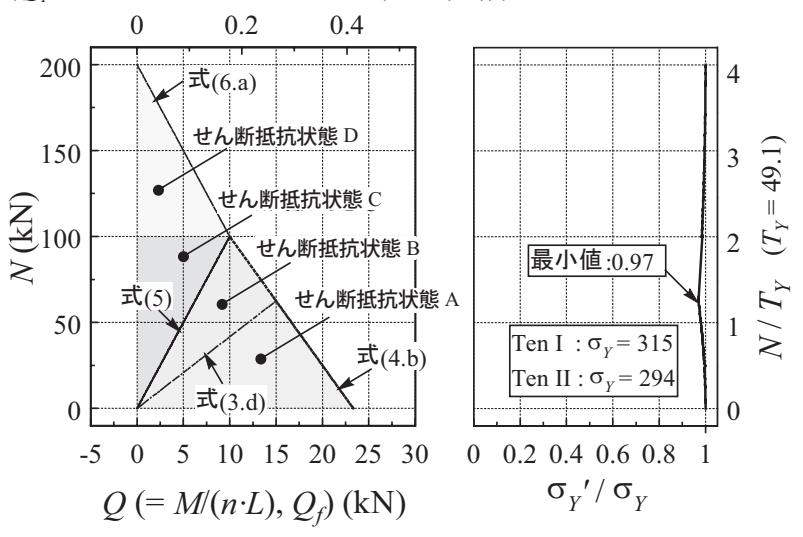

図 8 アンカーボルトに作用するせん断力と降伏応力度

\section{1 仮定}

以下の仮定に基づいて, 各評価式の導出, 並びに, 復元力特性モ デルの定式化を行う.

1. 降伏要素をアンカーボルトに限定する.

2. ベースプレートが基礎に接触している場合には, 圧縮合力点位置 は圧縮側ベースプレート端部とする.

3. 基礎, および, ベースプレートの弾性変形による弾性回転剛性の 低減を考慮するため, 係数 : $R$ を導入する ${ }^{1)}$.

4. ベースプレートが基礎に接触している場合には, 引張側アンカー ボルトのみが抵抗する.

5. 柱せん断力には, ベースプレートが基礎に接触している場合には, ベースプレートと基礎との間に発生する摩擦力で抵抗する. しか しながら, 摩擦力は基礎からの圧縮反力: $C$ とベースプレートと基 礎間の静止摩擦係数 : $\mu$ により決定するため, 柱軸力が引張軸力領 域に入る場合, 図 7 (b) に示すように摩擦力のみではせん断力を負 担できない場合がある.更に, 図7 (c), (d)に示すようにベースプレー トと基礎とが離間している場合には，アンカーボルトのせん断力 で抵抗する. 本論文では, 定式化の簡単のために, 図 7 (b) (d) に 
示す抵抗機構となる場合，全て，軸力に対して主に抵抗している 側のアンカーボルト列が負担するものとして考える.

図 7 (a) より，柱脚部に作用するせん断力 : $Q$ と摩擦力によるせん 断力: $Q_{f}$ とは以下の式で表すことができる.

$$
\begin{aligned}
& Q=\frac{M}{L}=\frac{n \cdot T \cdot\left(d_{t}+d_{c}\right)-N \cdot d_{c}}{L} \\
& Q_{f}=C \cdot \mu=(n \cdot T-N) \cdot \mu
\end{aligned}
$$

また, これらが釣合っている時の柱軸力 $: N$ は以下の式で表すこ とができる。

$$
N=\frac{n \cdot T \cdot\left(\mu \cdot L-d_{t}-d_{c}\right)}{\mu \cdot L-d_{c}}
$$

この時, 柱脚部に作用するせん断力 $: Q$ は,

$$
Q=Q_{f}=(n \cdot T-N) \cdot \mu=\frac{n \cdot T \cdot \mu \cdot d_{t}}{\mu \cdot L-d_{c}}
$$

となる.

ここに, $n$ :引張側アンカーボルト本数, $d_{t}$ : 柱断面図心位置から 引張側アンカーボルト中心までの距離, $d_{c}$ : 柱断面図心位置から圧 縮合力点位置までの距離, $N$ : 鉛直荷重（引張軸力を正 $(+)$ とする）, $L$ : 柱長さ $(=1.5(\mathrm{~m})), \mu$ :ベースプレートと基礎間の静止摩擦係数 $(=0.4)^{24)}$ である.

図 8 に，各軸力下でアンカーボルトが負担するせん断力 ${ }_{a b} Q （$ 式 (3.d) 抢よび後述の式 (4.b), (5), (6.a) により求めた $M$ から算出した) と, ミーゼスの降伏条件によりせん断力の影響を考慮したアンカー ボルト降伏軸方向応力度と降伏応力度の比 $\sigma_{Y}{ }^{\prime} / \sigma_{Y}$ を示す. 尚, せん 断応力度には平均応力度 $\left(Q /{ }_{a b} A\right)$ を用い, また, 抵抗状態 $\mathrm{B}, \mathrm{D}$ に おいては危険側の值を検討するために $Q=Q_{1}\left(Q_{F}=0, Q_{2}=0\right)$ として算 出している. 図 8 より, 柱脚の降伏曲げ耐力については, $\sigma_{Y}^{\prime} / \sigma_{Y}$ の 最小值が 0.97 となり，アンカーボルトがせん断力を負担すること による影響は工学的に見て小さいと言える. このため, せん断力 が作用することによる，アンカーボルトの降伏軸耐力の低減はな いものとする.

一方，柱の水平弾性剛性については，アンカーボルトがせん断 力を負担する場合，柱の曲げ剛性と柱脚の回転による柱頭部水平 変位に, アンカーボルトの曲げ剛性による柱頭部水平変位, 更に, ベースプレートのアンカーボルト孔とアンカーボルトの間の遊び (ベースプレートには施工上過大孔を加工するため) による柱頭部 水平変位を累加する必要がある。このため, せん断抵抗状態 C, D では，柱の水平弾性剛性は著しく低下し，第 1 層柱の性状を検討 する上では十分に検討すべきであるが，復元力特性（曲げモーメ ント -ベースプレート回転角関係）上においてこれらの影響が現 れないため，本定式化ではこれらの影響を考慮しないものとする. 6. アンカーボルトの材料特性には, 完全弾塑性体モデルを用いる.

\section{2 抵抗機構と降伏曲げ耐力・弾性回転剛性}

図 6 に各抵抗機構を示す. 各抵抗機構が発生する軸力の領域, 各 評価式を以下に示す。

\subsection{1 抵抗機構 A ( 図 6 (a) )}

抵抗機構 $\mathrm{A}$ は, ベースプレートが基礎に接触している場合の抵抗 機構である．せん断力に対しては，ベースプレートと基礎との間に 発生する摩擦力により抵抗する. 尚, 抵抗機構 A は, 圧縮軸力領域 と引張軸力領域 I $\left(N<2 T_{y}\right)$ で発生する．柱軸力が引張軸力領域 II に
ある場合には，全てのアンカーボルトが引張抵抗するため, ベース プレートが基礎に接触しない.

次いで，仮定 2)より，圧縮合力点位置は圧縮側ベースプレート端 部とすれば,この抵抗機構における付加曲げ抵抗: $M_{A n}$, 降伏曲げ而力： $M_{A}$, および, 弾性回転剛性 $: K_{A B S}$ は, 以下の式で表される.

$$
\begin{aligned}
& M_{A n}=-N \cdot d_{c} \\
& M_{A Y}=n \cdot{ }_{a b} A \cdot{ }_{a b} \sigma_{Y} \cdot\left(d_{c}+d_{t}\right)-N \cdot d_{c} \\
& K_{A B S}=\frac{E \cdot n \cdot{ }_{a b} A \cdot\left(d_{c}+d_{t}\right)^{2}}{R \cdot{ }_{a b} \ell}
\end{aligned}
$$

ここに, ${ }_{a b} A$ : アンカーボルト軸部断面積, ${ }_{a b} \sigma_{Y}$ : アンカーボルト降 伏応力度, $E$ : アンカーボルトのヤング率, $R:$ ベースプレートと基礎 の弾性変形を考慮した低減係数 $(=2.0)^{1)},{ }_{a b} \ell$ : アンカーボルトの有効 長さである.

\subsection{2 抵抗機構 B ( 図 $6(b)$ )}

抵抗機構 B は, ベースプレートが基礎から離間し, 片側のアンカー ボルト列のナットがベースプレートに接触している場合の抵抗機構 である. せん断力に対しては, 図7(a) に示すように, ナットがベー スプレートに接触していない側のアンカーボルトがせん断抵抗する. 尚, 抵抗機構 $\mathrm{B}$ は, 引張軸力領域 $\mathrm{I}\left(0<N<2 T_{y}\right)$ で発生する. 柱軸力 が引張軸力領域 II にある場合には，全てのアンカーボルトで抵抗す る.

この抵抗機構における軸力曲げ抵抗: $M_{B n}$ は, 以下の式で表される.

$$
M_{B n}=N \cdot d_{t}
$$

\subsection{3 抵抗機構 C( 図 6 (c) )}

抵抗機構 $\mathrm{C}$ は, ベースプレートが基礎から離間し, 全てのアンカー ボルトのナットがベースプレートに接触している場合の抵抗機構で ある. せん断力に対しては, 図7(b) に示すように, 片側が降伏して いる場合, 降伏していない側のアンカーボルトがせん断抵抗する. 尚, 抵抗機構 $\mathrm{C}$ は，引張軸力領域 I・II $\left(0<\mathrm{N}<4 T_{y}\right)$ で発生する.

次いで, この抵抗機構における降伏曲げ耐力: $M_{C Y}$, および, 弾性 回転剛性 : $K_{C B S}$ は以下の式で表される.

$$
\begin{aligned}
& M_{C Y}=n \cdot{ }_{a b} A \cdot{ }_{a b} \sigma_{Y} \cdot\left(2 d_{t}\right)-N \cdot d_{t} \\
& K_{C B S}=\frac{E \cdot n \cdot{ }_{a b} A \cdot 2 \cdot d_{t}^{2}}{R \cdot{ }_{a b} l}
\end{aligned}
$$

\section{3 復元力特性モデル}

任意サイクル時の, 各一定軸力下における復元力特性モデルと抵 抗機構の変化を図 9 に示す.

\subsection{1 圧縮軸力領域 (Comp)}

柱軸力が圧縮軸力領域 (Comp) である場合については，一般的なス リップ型復元力特性モデルとなる ${ }^{1-8)}$. 尚, 常に抵抗機構 A となり, 付加曲げ抵抗, 降伏曲げ耐力, 弾性回転剛性は, 式 (4.a) (4.c)により 求められる。

\subsection{2 引張軸力領域 I (Ten I)}

柱軸力が引張軸力領域 I (Ten I) である場合の復元力特性モデルと抵 抗機構の変化を図 9(a) に示す．用いる理論式は，(4.b), (4.c), (5), (6.b) である. 


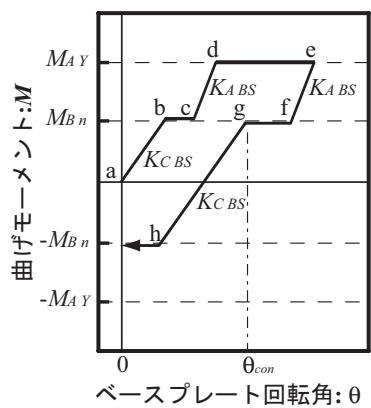

(a) 引張軸力領域 I (Ten I)

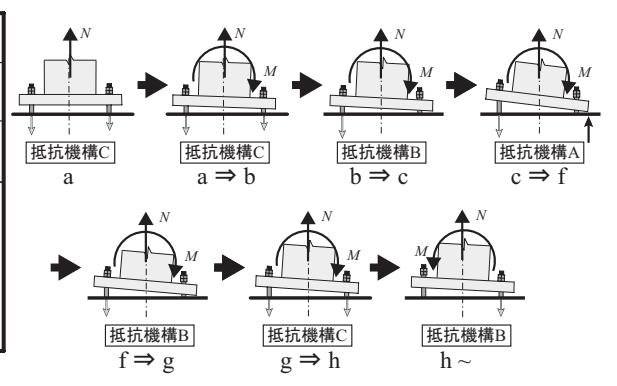

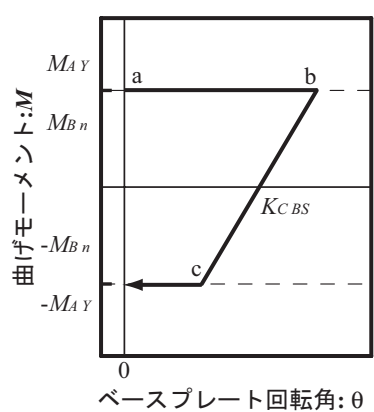

(b) 引張軸力領域 II (Ten II)

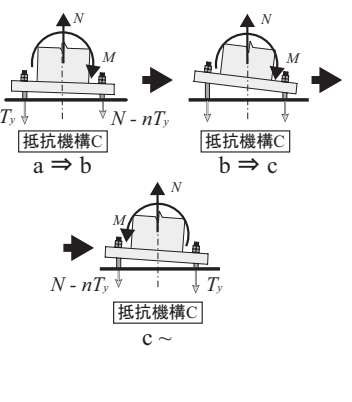

復元力特性モデルによる履歴の予測

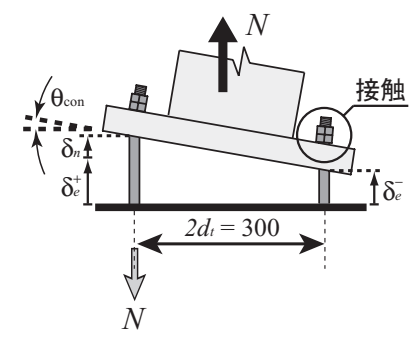

図 10 抵抗機構 B から抵抗機構 C となる瞬間の変形状態

任意サイクル時において, 圧縮側および引張側のアンカーボルト の塑性伸び量が等しければ, 回転角が 0 の状態で曲げ抵抗が 0 であり, 抵抗機構 $\mathrm{C}$ となる. この点 $\mathrm{a}$ から, 先ず, 抵抗機構 $\mathrm{C}$ でベースプレー トが回転し, 弾性回転剛性: $K_{C B S}$ で曲げモーメントが増加して行き (a $\Rightarrow b)$, 次いで, 圧縮側アンカーボルトのナットがベースプレートか ら離間して抵抗機構 $\mathrm{B}$ となり, 付加曲げ抵抗 : $M_{B n}$ で回転角が増大す る $(b \Rightarrow c)$. ベースプレートの圧縮側端部が基礎に接触して, 抵抗機 構 $\mathrm{A}$ となり, 弾性回転剛性: $K_{A B S}$ で曲げモーメントが増加した後, 降 伏曲げ耐力: $M_{A Y}$ に達して, 降伏曲げ耐力を保持したまま回転角が増 大する $(\mathrm{c} \Rightarrow \mathrm{e})$.

そして, 除荷を開始すると, 弾性回転剛性 : $K_{A B S}$ で曲げモーメント が減少し, 付加曲げ抵抗: $M_{B n}$ に達すると抵抗機構 B となり, 耐力を 保持したまま回転角が減少する $(\mathrm{e} \Rightarrow \mathrm{g})$.

次いで, 圧縮側アンカーボルトのナットがベースプレートに接触 して抵抗機構 $\mathrm{C}$ となり, 弾性回転剛性: $K_{C B S}$ で曲げモーメントが減少 する $(\mathrm{g} \Rightarrow \mathrm{h})$. 最後に, 引張側アンカーボルトのナットがベースプレー トから離間して, 再び, 抵抗機構 $\mathrm{B}$ となり, 負の付加曲げ抵抗 :- $M_{B n}$ を保持しながら回転角が減少する ( h ).

尚, 除荷時の履歴が原点を通らないのは, 圧縮側と引張側のアン カーボルトの塑性伸び量が異なるためである．また, 圧縮側アンカー ボルトのナットがベースプレートに接触する回転角 : $\theta_{\text {con }}$ (図 9 (a) 中 の点 g) は, 図 10 に示す幾何学的条件より, 引張側と圧縮側アンカー ボルトの塑性伸び量 $: \delta_{e}^{+}, \delta_{e}$, 引張軸力 $: N$ によるアンカーボルトの弾 性伸び量 $: \delta_{n}$ を用いて, 以下の式で表される.

$$
\begin{aligned}
\theta_{c o n} & =\tan ^{-1}\left(\frac{\delta_{e}^{+}+\delta_{n}-\delta_{e}^{-}}{2 d_{t}}\right) \\
& \doteq\left\{\left(d_{t}+d_{c}\right) \cdot\left(\theta_{\max }^{+}|-| \theta_{\max }^{-} \mid\right)+\frac{R \cdot N \cdot{ }_{a b} \ell}{n \cdot{ }_{a b} A \cdot E}\right\} \cdot \frac{1}{2 d_{t}}
\end{aligned}
$$

ここに, $\theta_{\text {max }}^{+}$: 任意サイクル時における正方向載荷の最大回転角, $\theta_{\text {max }}^{-}$: 任意サイクル時における負方向載荷の最大回転角である.

\subsection{3 引張軸力領域 II (Ten II)}

柱軸力が引張軸力領域 II (Ten II) である場合の復元力特性モデルと 抵抗機構の変化を図 9(b) に示す.

任意サイクル時において，ベースプレートが基礎から常に離間し， 抵抗機構 C となる. 載荷方向により, 降伏するアンカーボルトが入 れ替わるのみである.このため, 復元力特性モデルは, 式 (6.a) より 求められる降伏曲げ耐力: $M_{C Y}$ と, 式 (6.b) より求められる弾性回転 剛性 : $K_{C B S}$ を有する, 完全弾塑性型となる.

\section{4. 実験結果}

各実験結果を図 11 , 図 12 , 図 13 に示す。図 11 に曲げモーメント： $M$ - ベースプレート回転角 : $\theta$ の関係を, 図 12 にアンカーボルト軸力 : $T$-ベースプレート回転角 : $\theta$ の関係を, 図 13 に離間変位 : $\delta_{\mathrm{v}}-$ ベース プレート回転角 : $\theta$ の関係を示す.また, 図 11 においては, 復元力 特性モデルを併せて示す.

尚, 図 11 中の右縦軸と上横軸は, 式 (4.b), (6.a) より求めた降伏曲 げ耐力解析值 : $M_{A Y}, M_{C Y}$ と式(4.b-c), (6.a-b) より求めた降伏時べース プレート回転角解析值: $\theta_{Y}$ で無次元化し, 図 12 中の右縦軸と上横軸は, アンカーボルト降伏軸力 : $T_{Y}$ と降伏時ベースプレート回転角 $: \theta_{Y}$ で無 次元化している.

\section{1 圧縮軸力領域 (Comp)}

柱軸力が圧縮軸力領域 (Comp) である場合, 図 11 (a) より, 実験結 果は一般的なスリップ型となり, 復元力特性モデルと良好に対応し ていることが分かる．図 12 (a) より，アンカーボルトは，降伏後にほ ぼ耐力が一定となり, 仮定 6), 4) の通り, 完全弾塑性型履歴性状を示 している. また，圧縮側アンカーボルトが抵抗していないこととス リップ現象が生じていることが分かる. 但し，1 2 サイクル目におい ては，アンカーボルトの塑性伸びが僅かであるため，全アンカーボ ルトのナットがベースプレートに常に接触しており, 圧縮側となる アンカーボルト（正方向載荷における右側ボルト）も抵抗している. 図 12 より, 左右どちらかのベースプレート端部が基礎に常に接触し ているため, 離間変位: $\delta_{v}$ はほぼ 0 であり, 常に抵抗機構 $\mathrm{A}$ となるこ とが分かる.

\section{2 引張軸力領域 I (Ten I)}

柱軸力が引張軸力領域 I (Ten I ) である場合，図 11 (b) より，実験結 果は，スリップ型で正負非対称な履歴性状を示し，復元力特性モデ ルと良好に対応していることが分かる. 引張軸力領域 I でも, 付加曲 げ抵抗が発生して, 全体の履歴性状は圧縮軸力領域のものと類似し ている. 降伏曲げ而力は, アンカーボルトが柱軸力を負担するため, Comp と比較して低下している．また，軸力曲げ抵抗する区間におい 


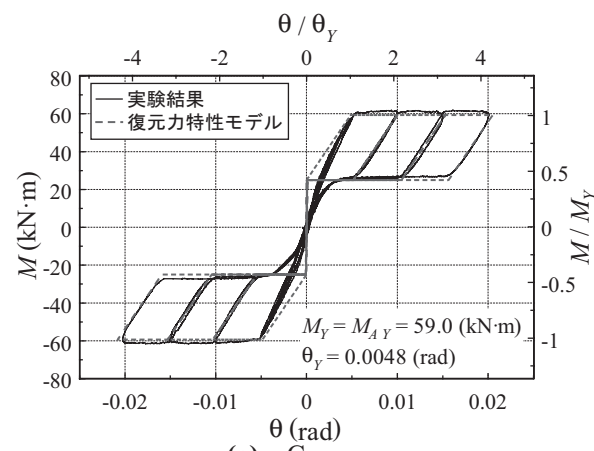

(a) Comp

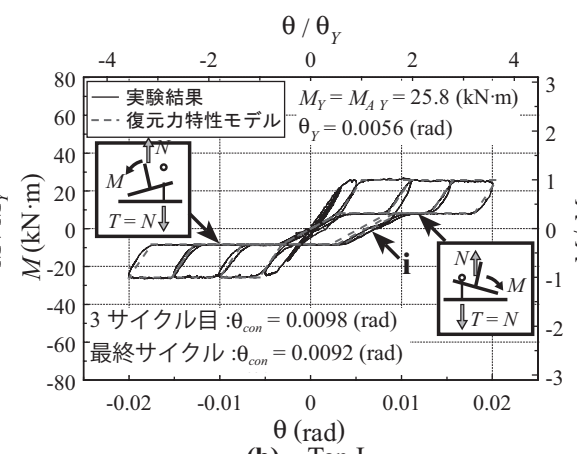

(b) Ten I

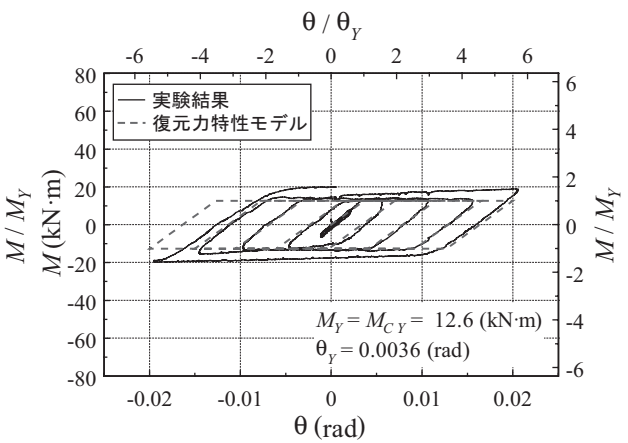

(c) Ten II

図 11 曲げモーメント:M-ベースプレート回転角 : $\theta$ 関係

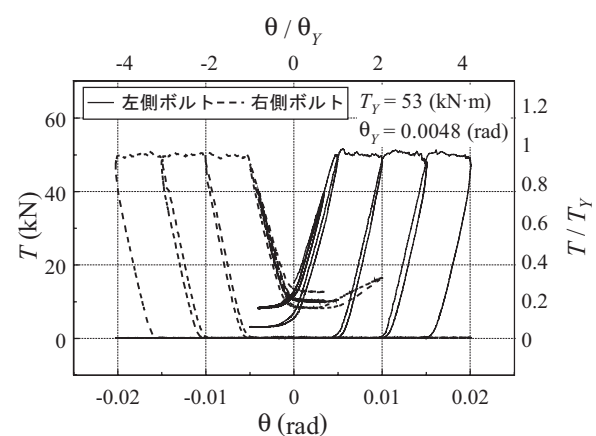

(a) Comp $\theta / \theta_{Y}$

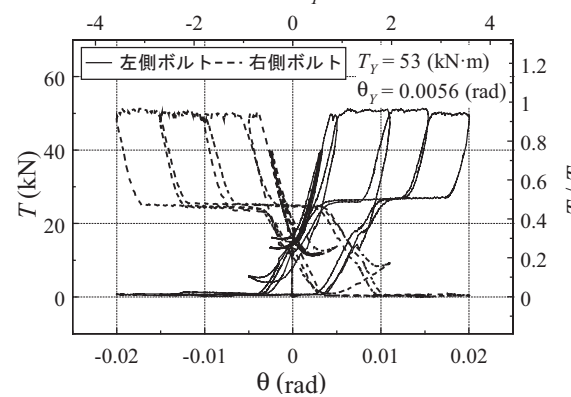

(b) $\mathrm{Ten} \mathrm{I}$ $\theta / \theta_{Y}$

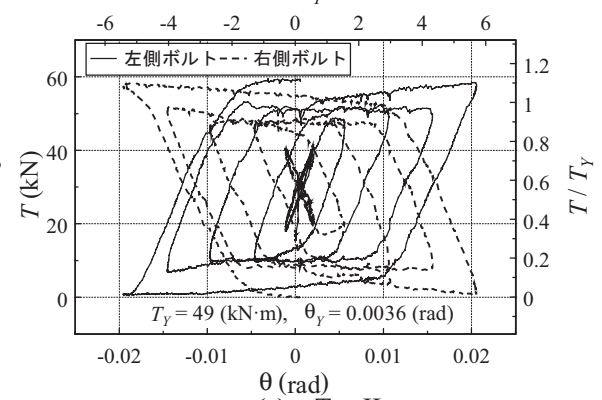

(c) Ten II

図 12 アンカーボルト軸力 $: T$-ベースプレート回転角 : $\theta$ 関係

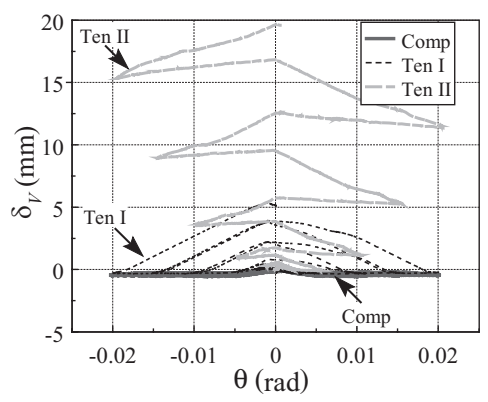

図 13 離間変位: $\delta_{v}$-ベースプレート回転角 : $\theta$ 関係

ては, 引張側のアンカーボルトのナットがベースプレートに接触し ており, 回転角と軸力曲げ抵抗は逆向きになる. 但し, 図 12 (b) よ り, 正方向載荷の除荷時において, $0.01(\mathrm{rad})$ 付近から圧縮側アンカー ボルト（右側ボルト）のナットがベースプレートに接触して抵抗機 構 C となり, 引張アンカーボルト（左側ボルト）の軸力が減少する と共に右側ボルトの軸力が増加し, 柱軸力を負担するアンカーボル ト列が切り替わる (図 9 (a) 中の $\mathrm{g} \Rightarrow \mathrm{h}$ 区間に相当). この影響により, 図 11 (b)のiに扔いて, 負の回転角に達する前に負の曲げ抵抗が発生 し, また, この現象が発生する回転角の予測值 : $\theta_{c o n}$ を図 11 (b) 中に 併せて記すが, 式 (7)により予測可能であることが分かる. このよう な, 回転角と曲げ抵抗の向き一致する現象は, 両側のアンカーボル トの塑性伸び量が異なる場合に生じる. ベースプレート回転角を制 御值とする正負交番繰返し載荷に扔いては, 負方向除荷時に両側の アンカーボルトの塑性伸び量が等しくなるため, このような現象は 発生しない.

図 13 より, 最大の離間変位: $\delta_{\mathrm{v}}$ が $5 \mathrm{~mm}$ 程度となり, 接触と離間と を繰返していることが分かる.これは, 付加曲げ抵抗する区間にお いてはベースプレートが基礎から離間して抵抗機構 $\mathrm{B} ・ \mathrm{C}$ となり, そ れ以外の区間においてはべースプレートが基礎に接触して抵抗機構
A となるためである。

\section{3 引張軸力領域 II (Ten II)}

柱軸力が引張軸力領域 II (Ten II) である場合, 図 11 (c) より, 実験 結果は完全弾塑性型を示し, 復元力特性モデルと良好に対応してい ることが分かる. 降伏曲げ耐力は, アンカーボルトが柱軸力を負担 するため, Ten I より大きな一定引張軸力を載荷している Ten II では, Ten Iより更に低下している. 但し, 最終サイクルにおいては, アンカー ボルトのひずみ硬化の影響により, 曲げ抵抗は増加している.

図 12 (c) より, 全てのアンカーボルトに常に軸力が作用しているこ と, そして, 図 13 より, 最大の離間変位: $\delta_{\mathrm{v}}$ が $20 \mathrm{~mm}$ 程度となり常 に離間変位が生じていることより, 常に抵抗機構 C となっているこ とが分かる.

\section{5. まとめ}

一定圧縮・引張軸力を受けるアンカーボルト降伏先行型露出柱脚 の水平繰返し載荷実験結果と抵抗機構に基づく復元力特性モデルと を比較・検討した結果, 以下のような知見が得られた.

1. 一定圧縮・引張軸力を受ける柱脚の復元力特性モデルは, 図 6 に 示す 3 種類の抵抗機構を用いて求められる.

2. 一定圧縮軸力を受ける柱脚の復元力特性モデルは, 図 6 (a) の抵抗 機構のみを用いて全弾塑性型として求められ, 実験結果に良好に 対応している.

3. 一定引張軸力を受ける柱脚の場合には, 引張軸力の大きさにより 復元力特性が異なる.

4. 引張軸力領域 I の一定引張軸力を受ける柱脚の復元力特性モデル は, 図 6 の全ての抵抗機構を用いて煩雑な曲線として求められる. 特に, 除荷時において, アンカーボルトの塑性伸び量の差異により, 履歴曲線が異なる性状を示す．すなわち, 基礎に接触していたべー 
スプレートが，離間し，そして，アンカーボルトのナットに接触 することによる抵抗機構 $\mathrm{A}, \mathrm{B}, \mathrm{C}$ の変化に伴う曲線が除荷時に異 なる場合がある.この性状を精確に追跡した復元力特性モデルは, 実験結果に良好に対応している.

5. 除荷時において，圧縮側アンカーボルトのナットがベースプレー トに接触する回転角は, 式 (7) を用いて精度良く求められる.

6. 引張軸力領域 II の一定引張軸力を受ける柱脚の復元力特性モデル は, 図 6 (c) の抵抗機構の夕を用いて完全弾塑性型として求められ, 実験結果に良好に対応している。

現在, 変動軸力を受けるアンカーボルト降伏先行型露出柱脚の水 平繰返し載荷実験を行っている，その実験結果については，報を改 めて報告を行う予定である．本論文で示した，抵抗機構および復元 力特性モデルを用いて, 引張軸力領域を含む変動軸力を受ける場合 の抵抗機構および復元力特性モデルを検討する. 更に, "楔デバイス” を設置した柱脚の復元力特性における, 変動軸力の影響についても 検討する予定である.

\section{謝辞}

本研究は, 広島工業大学「高性能構造システム開発研究センター」 (代表者 高松隆夫教授)のプロジェクト研究の一環として実施され ました．また，試験体の転造ねじアンカーボルトを提供していただ きましたフルサト工業株式会社，研究助成をしていただきました古 川技術振興財団に対して，感謝の意を表します。

\section{参考文献}

1) 秋山宏：鉄骨柱脚の耐震設計, 技報堂出版, 1985.3

2) 山西央朗, 玉井宏章, 高松隆夫, 松尾彰：露出柱脚の弾性回転剛性につ いて - アンカーボルト降伏先行型の場合 -, 日本建築学会構造系論文集, 第 623 号, pp.155-162, 2008.1.

3) 高松隆夫, 銅木弘和, 中村慎太郎 : 露出型柱脚の復元力特性に関する実 験的研究，鋼構造年次論文報告集，第 9 巻, pp.415-422, 2001.11。

4) 高松隆夫, 銅木弘和, 中村慎太郎 : 鉄骨露出型柱脚の復元力特性に関す る研究，鋼構造年次論文報告集，第 10 巻, pp.499-506, 2002.11.

5) 高松隆夫，銅木弘和，中村慎太郎：改良型復元力特性を有する鉄骨露 出柱脚に関する研究, 鋼構造年次論文報告集, 第 11 巻, pp.563-570, 2003.11.

6) 高松隆夫, 玉井宏章, 山西央朗, 石原節夫, 松尾彰 : 既存屋内運動場 露出柱脚の復元力特性について, 鋼構造年次論文報告集, 第 12 巻, pp.281-288, 2004.11.

7)Takao TAKAMATSU, Hiroyuki TAMAI: Non-slip-type restoring force characteristics of exposed-type column base, Journal of Constructional
Steel Reserch, Vol.61, pp.942-961, 2005.

8) 高松隆夫，玉井宏幸，山西央朗：ノンスリップ型鉄骨露出柱脚の復元力 特性モデル，構造工学論文集，Vol.51B,pp.293-302,2005.3.

9) 高松隆夫, 玉井宏章, 山西央朗, 松尾彰：ノンスリップ型露出柱脚のセ ルフセンタリング性能に関する研究，鋼構造年次論文報告集，第 13 巻, pp.173-180, 2005.11.

10)T. Takamatsu, H. Tamai, T. Yamanishi \& A. Matsuo (2006a), Self-centering performance of non-slip-type exposed column-base, Proceeding of fifth international conference on "Behaviour of Steel Structures in Seismic Areas(STESSA2006)”, Yokohama, Japan, 357-362.

11) 山西央朗，高松隆夫，玉井宏章，松尾彰：アンカーボルトを多数配列 したノンスリップ型露出柱脚の復元力特性 - 無軸力下の場合のセルフセ ンタリング性能 -, 日本建築学会構造系論文集, 第 621 号, pp.155-162, 2007.11.

12) 高松隆夫，玉井宏章，山西央朗，松村高良，石原節夫，松尾彰：既存 屋内運動場露出柱脚の復元力特性と楔デバイスによる耐震改修工法につ いて，構造工学論文集，Vol.54B,pp.715-722,2008.3.

13) 玉井宏章，高松隆夫，山西央朗，白木剛，多田元秀：統合化評価法を用 いた実大ノンスリップ型露出柱脚の仮動的実験，鋼構造年次論文報告集， 第 14 巻, pp.269-276, 2006.11

14) 伊藤倫夫, 三谷勲, 大谷恭弘, 藤永隆, 田中秀宣：基礎部の配筋を簡 略化したアンボンド型アンカーボルトを用いた露出柱脚の構造性能, 鋼 構造論文集，第 8 巻第 31 号, pp.43-55, 2001.9 .

15) 田中秀宣, 亀元靖彦, 三谷勲, 藤永隆, 伊藤倫夫 : 変動軸力を受ける 露出型柱脚の曲げ挙動と復元力特性, 鋼構造論文集, 第 10 巻 第 39 号, pp.39-49, 2003.9.

16) 田中秀宣, 三谷勲, 嶋村洋子, 伊藤倫夫 : 変動軸力を受ける露出柱脚 を有する鋼構造骨組の弾塑性挙動, 鋼構造論文集, 第 12 巻第 45 号, pp.171-184, 2005.3.

17) 田沼吉伸, 橋本健一：引張軸力を受ける露出形式柱脚の終局挙動, 鋼 構造年次論文報告集，第 6 巻，pp.181-188，1998.11。

18) 宗宮由典, 福知保長, 陳文慶 : 変動軸力を受ける露出型鉄骨柱脚の弾 塑性挙動及び耐力評価に関する実験的研究, 日本建築学会構造系論文集, 第 562 号, pp.137-143, 2002.12.

19) 玉井宏章：変動軸力と繰返し曲げを受ける露出柱脚の載荷実験 - 変 動軸力下の半剛接特性 -, 日本建築学会構造系論文集, 第 567 号, pp.149-156, 2003.5

20) 玉井宏章：変動軸力の影響を考慮した露出柱脚付骨組の弾塑性解析法, 日本建築学会構造系論文集, 第 571 号, pp.127-135, 2003.9.

21) 九谷和秀, 増田貫志 : 鉄骨構造露出柱脚部終局耐力に関する実験的研 究, , 日本建築学会論文報告集, 第433 号, pp.39-49,1992.3.

22) 松村高良, 高松隆夫, 玉井宏章, 山西央朗, 小澤拓雄, 松尾彰: 一定軸力 下の鉄骨露出柱脚の復元力特性モデル, 日本建築学会大会学術講演梗概 集 ( 九州)，構造 III-C1,pp.725 -726,2007.8

23) 高松隆夫, 玉井宏章, 松村高良, 山西央朗, 松尾彰：一定軸力下の 鉄骨露出柱脚の復元力特性モデル, 鋼構造年次論文報告集, 第 15 巻, pp.97-104, 2007.11.

24) 日本建築学会：鋼構造接合部設計指針，第 2 版，2006.3. 